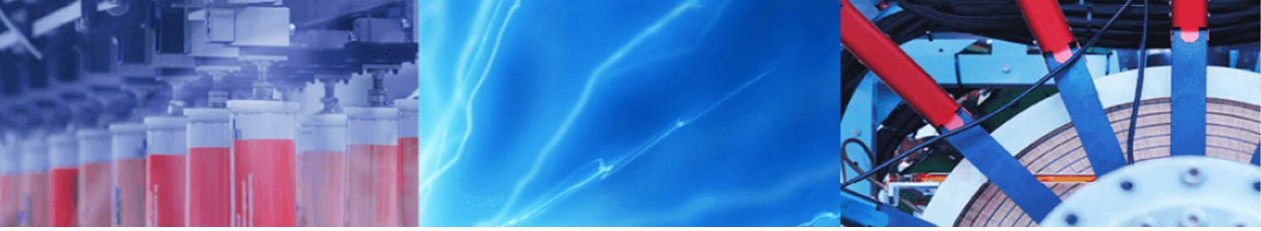

Research Article

\title{
Simulation of air temperature and their influence on the potential distribution of Myracrodruon urundeuva, Copernicia prunifera and Cereus jamacaru in the Caatinga
}

\author{
Luciana Cristina de Sousa Vieira ${ }^{1}$ (1) $\cdot$ Vicente de Paula Silva Filho ${ }^{1} \cdot$ Prakki Satyamurty $^{2,3}$. \\ Vanessa de Almeida Dantas ${ }^{1}$. Aldeize da Silva Santos ${ }^{2,3}$. Glayson Francisco Bezerra das Chagas ${ }^{4}$
}

Received: 22 August 2021 / Accepted: 19 November 2021

Published online: 18 December 2021

(C) The Author(s) 2021 OPEN

\begin{abstract}
Areas in the process of aridification in Caatinga phytogeographic domain in northeastern Brazil increase every year due to human intervention and increase in air temperature. The identification of long-term patterns and air temperature trends in the phytogeographic domain can express climate variability as well as a new phase of adaptation to some plant species. The temperature series from 1951 to 2018 obtained from the National Centers for Environmental Prediction data sets in four conservation areas with native vegetation, located in the North (A1), East (A2), South (A3) and West (A4) regions of this phytogeographic domain, show an increase in temperature between 0.5 and $1.4^{\circ} \mathrm{C}$ over the 68 -year period with the highest warming occurring in the months of March, April and May. The Maxent model is used to identify the influence of this increase on the presence potential of three species in the Caatinga, Myracrodruon urundeuva (aroeira), Copernicia prunifera (palmeira) and Cereus jamacaru DC (cactus) in the future time interval of 2041 to 2060, considering IPCC projected climate changes. The results show that climate change can lead to a reduction as well as redistribution of the potential areas of occurrence of the three species. Notable changes are: in the case of Carnauba, the high potential area reduces from $25.3 \%$ in the present state to $19.6 \%$ in 2050, and potential area for Aroeira diminishes in central Bahia and increases in Rio Grande do Norte. The projected changes for all three species are discussed.
\end{abstract}

Keywords Caatinga $\cdot$ Phytogeographic domain $\cdot$ Climate change $\cdot$ Aridification $\cdot$ Warming $\cdot$ Maxent model

\section{Introduction}

The Caatinga phytogeographic domain is the only type of plant formation that is exclusively Brazilian [4]. Earlier studies indicate that this phytogeographic domain has a great wealth of habitats and species, many of which are exclusive to the eastern portion of Brazil [39]. Many of the Caatinga species provide essential ecosystem services for the population, such as the development of phytopharmaceuticals [46] and biodiversity. This phytogeographic domain covers almost $10 \%$ of the Brazilian territory with a high rate of endemism. The Caatinga is among the most

Luciana Cristina de Sousa Vieira, vieirameteorologia@gmail.com; Vicente de Paula Silva Filho, vicente.silva@inpe.br; Prakki Satyamurty, saty.prakki@gmail.com; Vanessa de Almeida Dantas, vanessalmeida24@gmail.com; Aldeize da Silva Santos, aldeizesantos@yahoo.com.br; Glayson Francisco Bezerra das Chagas, chagasmeteorologista@gmail.com | ${ }^{1}$ National Space Research Institute, Estrada Do Fio, 5624-6140 - Mangabeira, Eusébio, CE 61760-000, Brazil. ${ }^{2}$ National Space Research Institute, São José dos Campos, Av. dos Astronautas, 1758 Jardim da Granja, SP CEP 12227-010, Brazil. National Amazon Research Institute, Av. André Araújo, 2936 - Petrópolis, Manaus, AM CEP 69080-971, Brazil. ${ }^{4}$ Secretaria de Estado de Meio Ambiente E Sustentabilidade - SEMAS/PA, Belém, PA, Brazil. 
altered phytogeographic domains, almost $50 \%$ of the alteration is anthropogenic through habitat destruction and fragmentation.

According to Seddon et al. [52], the Caatinga showed high sensitivity to climate variability in the last 14 years, mainly associated with variations in water availability and increased air temperature. The increase in global air temperature is attributed to the increases in the concentrations of greenhouse gases (GHG) in the atmosphere. Although greenhouse effect is natural and essential for the maintenance of life on the planet, the increase in GHG concentrations elevates the mean temperature of the planet.

The impacts of new climate conditions due to changes in atmospheric composition were investigated through projections of future scenarios, including the so-called representative concentration pathways (RCP) of the International Panel for Climate Change (IPCC) AR5 derived from the global climate model HadGEM2-ES simulations [8]. The pathways are named according to the levels of radiative forcing $[49,54]$. The IPCC AR5 report is based on the RCP4.5 and RCP8.5 scenarios which consist of changes in greenhouse gas concentrations, aerosols and land use and land cover for the twenty-first century [57], suggesting a radiative forcing $\left(\mathrm{W} \mathrm{m}^{-2}\right)$ that would be caused by the increase in the retention of incident solar energy [55]. The RCP4.5 scenario assumes that the radiative forcing will stabilize shortly after 2100 at around $4.5 \mathrm{~W} \mathrm{~m}^{-2}$ and the $\mathrm{RCP} 8.5$ scenario assumes a high radiative forcing of around $8.5 \mathrm{~W} \mathrm{~m}^{-2}$ by the end of the twenty-first century $[26,54]$. Zanin et al. [63] observed that, despite the Caatinga and the Cerrado (another Brazilian phytogeographic domain) showing greater resilience against climatic variability and less vulnerability in all scenarios, they may suffer a reduction in their optimal climatic space.

The global temperature projections point to midtwenty-first century increases of up to $2^{\circ} \mathrm{C}$ in air temperature ( $T_{-}$air), indicating the possibility of extinction of the phytogeographic domain due to a decrease in the system's water replacement capacity [53]. In the RCP4.5 scenario, the increase in $T_{-}$air can be up to $2.1^{\circ} \mathrm{C}$ and for RCP8.5 it can be higher, up to $4^{\circ} \mathrm{C}$ [20]. The increase in $T$ _air associated with climate changes due to global warming could increase evaporation from lakes, weirs, reservoirs and plant transpiration [36]. The increase in the output of water from the vegetation system, due to the increase in $T_{-}$air, makes the soil drier, causing damage to the plants [37]. Thus, the increase in $T_{\text {_air }}$ can lead to a decrease in carbon sequestration by vegetation.

In addition to the changes that the Caatinga can undergo due to climate changes, there are other factors that lead to environmental degradation, such as deforestation. Data from the Instituto Chico Mendes de Conservação da Biodiversidade (ICMBIO) of Brazil show that the total territory of the Caatinga is over 844 thousand $\mathrm{km}^{2}$, with $46 \%$ of it being illegally deforested and exploited (ICMBIO, 2020).

The present study evaluates T_air trends over four conservation areas in northeastern Brazil (NEB), in the period 1951-2018, and their possible impacts on the species Myracrodruon urundeuva (aroeira), Copernicia prunifera (carnaúba) and Cereus jamacaru DC (mandacarú). These are three plant species present in the Caatinga with high socioeconomic value for the region [7].

The impacts of the projected future climate on the presence of the three species are obtained by the Maxent model [15]. This is an attempt to observe whether changes in the climatic conditions for the phytogeographic domain can lead to the decline of these species, which would lead not only to negative consequences for the vegetative composition of the phytogeographic domain, but also to economic losses for the region.

\section{Material and methods}

\subsection{Study area}

The study is carried out on four areas of native Caatinga vegetation in the conservation units located in the North (A1), East (A2), South (A3) and West (A4) of the phytogeographic domain shown in Fig. 1. A1 is the national park of Furna Feia which, with an area of 8518 ha, is located in the municipalities of Mossoró and Baraúna in the state of Rio Grande do Norte. A2 is the Raso da Catarina ecological station, the driest region in the State of Bahia that has very sandy, deep and infertile soils. In this location, the Caatinga is shrubby and very dense [58]. A3 is Serra do Barbado, with 63,652 ha of preserved Caatinga, located in the state of Bahia. A4 is called Dunas e Veredas of the Lower-Middle São Francisco basin, which, also in the state of Bahia, was created in 1997, and extends over 106 ha. Dunas e Veredas is located in the municipalities of Barra, Pilão Arcado and Xique-Xique.

\subsection{Weather data}

Surface air temperature ( $T_{-}$air) data are obtained from the NCEP/NCAR numerical prediction and data assimilation systems [27], and from meteorological stations of the National Institute of Meteorology (INMET) located close to the chosen conservation areas. In the first stage of the analysis of the meteorological data, the correlation coefficients $\left(R^{2}\right)$ between the NCEP rainfall data and the historical data of the INMET conventional stations were calculated. The criterion for choosing the closest station to compare with the NCEP rainfall data was based on the 


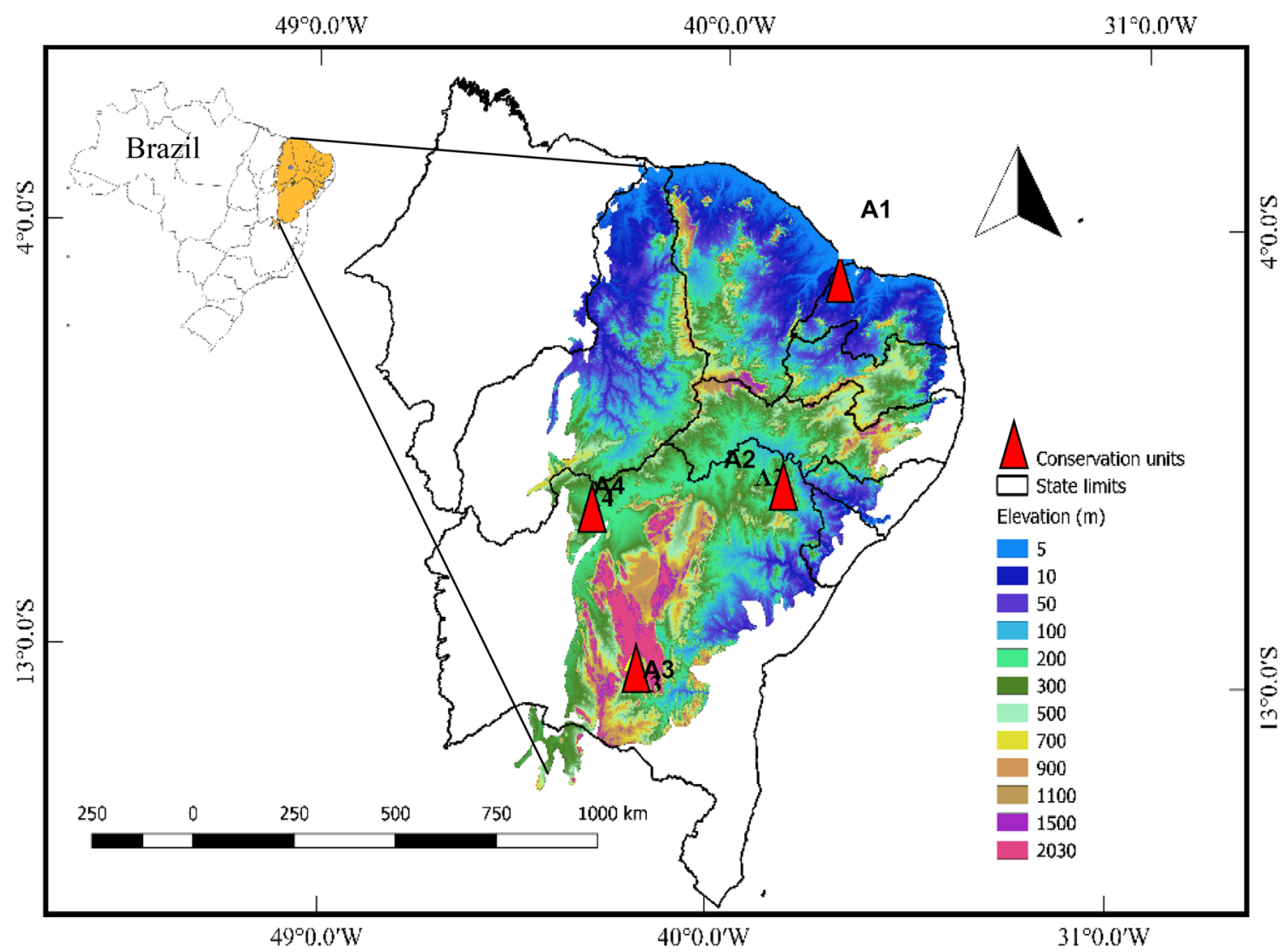

Fig. 1 Altitude map of the Caatinga phytogeographic domain, located in northeastern Brazil. The red triangles indicate the conservation units, Furna Feia (A1), Raso da Catarina (A2), Rio de Contas (A3) and Dunas e Veredas of the Lower-Middle São Francisco (A4)

rainfall atlas of Brazil published by CPRM [9] through the analysis of annual isohyets. If the study area does not have a meteorological station, then the closest station to the study site is known and whether this station is climatologically within the same isohyet area for the study area. The four stations chosen were Apodi station (closest to A1) located at latitude -5.63 and longitude -37.83 , Paulo Afonso station (closest to A2) located at latitude -9.37 and longitude - 38.22, Itaucu (para A3) located at latitude -13.82 and longitude -41.30 and finally for A4, Barra station was used, located at latitude -11.08 and longitude -43.14 .

Monthly mean values of $T_{\text {_air }}$ and precipitation over a regular grid with $0.5^{\circ}$ lat $X$ lon spacing are obtained directly from NCEP reanalysis. The area-mean $T$ _air values over the conservation units are obtained by taking simple averages of the reanalysis grid point values and the INMET station value. The time series of area-mean monthly temperatures over the conservation areas are plotted for the 68 years of data, starting in January 1951 until December 2019 , and the trends are obtained using the R software. The monthly rainfall data at the INMET stations are used to describe the seasonality of rainfall at the four conservation units.

\subsection{Species description}

The aroeira (Myracrodruon urundeuva) is a slow growing tree species, late flowering and gives good quality wood. It is not endemic and occurs in the northeastern, centralwestern and southeastern regions [7] of Brazil. According to the ecological group, it is a species considered late secondary [16]. The Ministry of the Environment classified aroeira as one of the most important species for preservation, indicating its four most important uses: beekeeping, wood, medicinal, producing oil and waxes [38]. It is a species with wide geographic distribution and great ecological plasticity, easily seen in the coastal zone of the country, close to water bodies such as rivers, streams and wetlands, and it can also grow in dunes and dry and rocky terrains [43]. The number of recorded points of presence of the aroeira species for this study is 83 . Its population density is around 6 trees per ha.

The carnauba (Copernicia prunifera) is a species of palm tree native to Brazil that usually occurs near rivers and 
marshy areas, preferring clayey and alluvial soils, being quite resistant to high levels of salinity. It also has a high capacity to adapt to heat, withstanding $3000 \mathrm{~h}$ of sunshine per year. According to Duque [13], the age of the palm trees, the type of soil, the climate and the proximity to the sea are factors that influence the production of wax. This native palm tree, admirably adapted to the climatic conditions of the semiarid tropics, has extraordinary resistance, both to the most severe droughts and to floods, two variables determined by the rainfall in the region. According to IBGE $[24,22]$, this is one of the most important species in the Caatinga, both in terms of productivity and in financial terms, offering non-timber forest products. The number of recorded points of presence of the Carnauba species for this study is 64 . Its population density is around 18 trees per ha.

The mandacaru (Cereus jamacaru P.) is a native species of the Caatinga vegetation, belonging to the Cactaceae family. It grows in stony soils and together with other species of cactus, forms the typical landscape of the semiarid region of the northeast Brazil, found in the states of Piauí, Ceará, Rio Grande do Norte, Paraíba, Pernambuco, Alagoas, Sergipe, Bahia and northern Minas Gerais. Mandacaru plants develop in the drier areas of the northeastern semiarid, in shallow soils and/or on top of rocks, multiplying regularly and covering large areas, showing themselves adaptable to the edaphoclimatic conditions of these regions [19]. The number of recorded points of presence of the mandacaru species for this study is 63 . Its population density is around 8 bushes per ha.

\subsection{Modeling with Maxent}

The Maxent model is a tool used for modeling the potential distribution of species, relating their places of occurrence with environmental characteristics [15]. Bioclimatic variable maps, elevation map and species presence records are used as input data. The model gives us the abundance of a given species in terms of percentage number of pixels (or cells) occupied by the species. It also gives us the performance statistic known as area under the curve (AUC).

Spatial data of bioclimatic variables with a resolution of $30 \mathrm{~s}$ of a degree of latitude and longitude $(\sim 1 \mathrm{~km})$, cropped for the Caatinga phytogeographic domain, are obtained from the website http://worldclim.org (v.1.4) for the period from 1970 to 2000 (historical data). The terrain elevation (Fig. 1) data are obtained from http://eros.usgs. gov.

From the simulations with the climatic conditions of the RCP4.5 and RCP8.5 scenarios, processed by the HadGEMES global model (Hadley Global Environment Model 2Earth System), bioclimatic variable data for the period from
2041 to 2060, centered on 2050, are obtained from the website http://worldclim.org [21]. The bioclimatic variables are: $\mathrm{BIO} 1$ - average annual temperature, $\mathrm{BIO} 2-$ mean diurnal range (mean of monthly (max temp-min temp)), BIO3-isothermality $(\mathrm{BIO} 2 / \mathrm{BIO})(\times 100), \mathrm{BIO} 4$-temperature seasonality (standard deviation $\times 100$ ), BIO5-maximum temperature of warmest month, $\mathrm{BIO6}-$ minimum temperature of coldest month, $\mathrm{BIO}$-temperature annual range ( $\mathrm{BIO} 5-\mathrm{BIO}), \mathrm{BIO}$ - mean temperature of wettest quarter, $\mathrm{BIO}$ - mean temperature of driest quarter, $\mathrm{BIO10}$ - mean temperature of warmest quarter, $\mathrm{BIO} 11-$ mean temperature of coldest quarter, $\mathrm{BIO12-annual}$ precipitation, $\mathrm{BIO} 13$ - precipitation of wettest month, $\mathrm{BIO14-precipitation} \mathrm{of} \mathrm{driest} \mathrm{month,} \mathrm{BIO15}$ - precipitation seasonality (coefficient of variation), BIO16-precipitation of wettest quarter, $\mathrm{BIO17-precipitation} \mathrm{of} \mathrm{driest}$ quarter, $\mathrm{BIO18}$ - precipitation of warmest quarter, $\mathrm{BIO} 19$ precipitation of coldest quarter.

Before feeding the Maxent model with bioclimatic variable data, principal component analysis (PCA) is performed for each of the variables in combination with the presence distribution data for a given species. Principal component analysis (PCA) is a method whose basic purpose is to analyze the data used in order to reduce it, eliminate overlaps and choose the most representative forms of data based on linear combinations of the original variables. The goal is to reduce the number of variables. Correlation coefficients between each pair of principal components obtained for the different variables are calculated. (That is, the principal component obtained for a bioclimatic variable, say $\mathrm{V} 1$, is correlated with the principal components obtained for $\mathrm{V} 2$, V3, etc. Likewise, the principal component of V2 is correlated with those of $\mathrm{V} 3, \mathrm{~V} 4$, etc., and so on.) If the correlation between the principal components of any two bioclimatic variables, in combination with the presence distribution, is 0.7 or greater, only one of the variables is considered to affect the species of plants, thus reducing the number of environmental variables that enter the model $[60,11]$. The understanding involved is that if two variables that affect plant species are strongly correlated, one of the two variables is sufficient to model the potential presence of the species.

With the procedure given above, besides the elevation map used for all the three species, $\mathrm{BIO1}, \mathrm{BIO19}, \mathrm{BIO}$, $\mathrm{BIO} 5, \mathrm{BIO} 9, \mathrm{BIO} 8, \mathrm{BIO} 13, \mathrm{BIO} 1$ are chosen for Myracrodruon urundeuva (aroeira). For Copernicia prunifera (carnaúba) $\mathrm{BIO} 1, \mathrm{BIO} 4, \mathrm{BIO}, \mathrm{BIO}, \mathrm{BIO} 17, \mathrm{BIO} 18, \mathrm{BIO} 2$ are chosen. For Cereus jamacaru DC (mandacarú), BIO12, BIO14, BIO2, $\mathrm{BIO}, \mathrm{BIO} 13, \mathrm{BIO} 4, \mathrm{BIO} 18$ are chosen.

Species presence data used as input to the model are in the form of decimal geographic coordinates. The location coordinates of each species are obtained from two online databases, SpeciesLink and Global Biodiversity 
Information Facility (GBIF). Each of the points obtained was individually visualized, in order to avoid duplicate records and to check if geographic position is wrongly inserted in water bodies or within urban areas. The three species selected for this study are chosen due to their socioeconomic importance for the Caatinga region. The present study is an attempt to project whether changes in the climatic conditions in the phytogeographic domain can lead to the decline of these species, which would lead not only to negative consequences for the vegetative composition of the phytogeographic domain, but also to economic losses for the region.

The validation of the model is based on the analysis of the area under the curve (AUC) which represents the overall accuracy or performance of the model, taking into account the influence of all the variables for which the species is sensitive. Maxent generates relative operating curves (ROC) from contingency tables of 'hits' and 'falsealarms' for different cutoff values of presence potential. The area under the ROC curve is the AUC and is calculated from the model projections and the observed species presence data for the present state. The AUC represents an independent index that assesses the discriminatory power of a model [47] and its calculation provides a unique measure of the model's performance, regardless of the previous choice of cutoff limits for obtaining ROC, as the curve is constructed from multiple cutoff limits (each cutoff limit being responsible for one point on the curve). The AUC value ranges from 0 to 1 . An AUC value of 0.50 or less indicates that the model did not perform well, whereas an AUC value of 1.0 indicates total accuracy to discriminate the species [14]. Further details of the model and its performance evaluation are found in Elith et al. From the Maxent output data, maps are prepared in QGIS (Quantum Gis, V. 2.18) that show the potential distribution of species, through climate changes imposed by the scenarios of future projections, the RCPs.

\subsection{Statistical treatments}

The climatological characterization of a region is normally based on 30 years of data. Thus, the NCEP data series from 1951 to 2019 are divided into two parts of 34 years each (January 1951 through December 1984 and January 1985 through December 2019) generating two successive climatologies that could be compared in order to easily visualize whether the locations (conservation units) had T_air changes. Statistical treatment is performed using $\mathrm{R}$ software version 3.4.4.

Initially, a graphical and descriptive analysis of the series and the tests by Mann-Kendall (MK) and Pettitt are observed. The Mann-Kendall test is a nonparametric test $[31,34]$, suggested by the Meteorological Organization
(WMO) for trend assessment in environmental data time series. This test is suitable for detecting climatic changes in meteorological series. MK considers that, in the hypothesis of stability of a time series, the succession of values occurs independently and the probability distribution must always remain the same, characterizing a simple random series. It is best suited as a test to see whether the time series values tend to increase or decrease over time (monotonic change). The MK test, when compared to other parametric tests, is more robust in terms of deviations from normality and non-stationarity of historical series data, justifying its wide use in trend studies [3]. This test, together with Kendall's Tau correlation statistic $(\tau)$, is commonly used to assess trends in environmental, climatological and hydrological data [1].

In the MK test, a trend is considered negative or positive, indicating a decrease or increase in the attributes of the analyzed time series, if the Mann-Kendall score (Kendall's tau) is negative or positive, respectively. Furthermore, the trend indicated by this methodology is considered significant when the $\mathrm{p}$ value is lower than $a=0.05$. As it is a nonparametric test, it has the advantage of not requiring the data series to be normally distributed [62]. However, the method requires the data to be independent and homogeneous [40]. The homogeneity of the data was tested according to the methodology proposed by Thom [56], verifying that the series is homogeneous. In the entire series, no flaws were found, a fact that did not require any special treatment to the data.

In turn, the nonparametric Pettitt statistical test [45] performs the verification of two entities, Y1, Y2, .., Yt and $\mathrm{Yt}+1, \mathrm{Yt}+2, \mathrm{YT}$, coming from different in the same way. This methodology is able to locate the point where there was a sudden change (point of change) in the mean of the time series, in addition to providing information on the homogeneity of the data in the analyzed series.

\section{Results}

\subsection{Analysis of rainfall and air temperature ( $T_{-}$air)}

The correlation coefficients between the NCEP data and the Apodi station (closest to A1) was $R^{2}=0.8$. Between NCEP and Paulo Afonso station (closest to A2) it was $R^{2}=0.7$, between NCEP and Itauçu (closest to A3) it was $R^{2}=0.7$, and finally for $A 4$, Barra station was used, located in the state from Bahia, with $R^{2}=0.65$.

The rainy season lasts about four months for $A 1$ and $A 2$ conservation areas from January to April and about five months for A3 and A4 from November to March. The dry period lasts about seven months, from June to November for $\mathrm{A} 1$ and $\mathrm{A} 2$ and from April to October for $\mathrm{A} 3$ and $\mathrm{A} 4$. 
The average accumulated rainfall values are higher for $A 1$ and $A 2,1480 \mathrm{~mm}_{\text {year }}{ }^{-1}$ and $1238 \mathrm{~mm}_{\text {year }}{ }^{-1}$, respectively, than for $A 3$ and $A 4$ which receive $753 \mathrm{~mm}_{\text {year }}{ }^{-1}$ and $704 \mathrm{~mm}_{\text {year }}{ }^{-1}$, respectively. The Intertropical Convergence Zone (ITCZ) is the most important rain-producing system for the northern part of northeast Brazil (NEB) (Ferreira et al., 2005) and affects $A 1$ area. The atmospheric systems that most contribute to rainfall in $A 2, A 3, A 4$ are the high-level cyclonic vortex (HLCV), remnants of frontal systems approaching from the south mainly during January to March season and to a lesser degree the ITCZ [51].

The monthly mean $T$ _air values and their trends for the four areas are shown in Fig. 2. The place with the highest mean $T_{-}$air is $\mathrm{A} 1$ despite having the highest amount of rainfall recorded over 68 years. This characteristic is due to its location, which is in an area of Northern Sertaneja Depression, with an average altitude of about $100 \mathrm{~m}$. It is known that areas with lower altitudes tend to be warmer and with smaller thermal amplitudes. A2 has an average altitude of $276 \mathrm{~m}$, and an average $T_{\text {_air }}$ of $23.8^{\circ} \mathrm{C}$. A3 is mountainous and has altitudes ranging between 480 and $2021 \mathrm{~m}$, with the lowest accumulated annual rainfall, perhaps in a rain shadow region. The lowest mean value of $T_{-}$ air $\left(22.2^{\circ} \mathrm{C}\right)$ of the NEB region occurs at A3. A4 has an average altitude of around $870 \mathrm{~m}$ but has warmer temperature and higher rainfall than A3. Figure 2 shows systematic and generalized increase in $T_{\text {_air }}$ in all the four locations.

The MK and Pettitt test results for the mean monthly $T_{\text {_air }}$ are given in Table 1 . The MK test clearly indicates that air temperatures have increased in all areas. The average annual values showed positive trends $(\tau=+0.025,+0.171,+0.181$ and +0.267$)$ and all these trends are statistically significant ( $p$ value $<a=0.05$ ). The Pettitt test showed positive $T$ _air changes for A1 and A2 since 1996. For $A 3$, the highest positive trend occurred from 1993 and for A4 from 1997.

Table 1 Mann-Kendall test applied to the four regions for air temperature. Observed trend $\left({ }^{\circ} \mathrm{C} /\right.$ year $)$

\begin{tabular}{|c|c|c|c|c|c|}
\hline \multicolumn{4}{|c|}{ Mann-Kendall } & \multicolumn{2}{|l|}{ Pettitt } \\
\hline Area & Tau & $p$ value & S.G & $p$ value & Year \\
\hline $\mathrm{A} 1$ & 0.25 & 0.018 & Y & $2.2 \mathrm{e}-16$ & May/1996 \\
\hline $\mathrm{A} 2$ & 0.171 & $2.22 \mathrm{e}-16$ & Y & $1.4 \mathrm{e}-11$ & July/1996 \\
\hline A3 & 0.181 & $5.116 \mathrm{e}-12$ & $\mathrm{Y}$ & $2.2 \mathrm{e}-16$ & June/1993 \\
\hline A4 & 0.267 & 0.0216 & Y & $2.2 \mathrm{e}-16$ & June/1997 \\
\hline
\end{tabular}

S.G: statistical significance at 5\% level, Y (yes) or N (no). Pettit: Pettitt trend, year: the year since
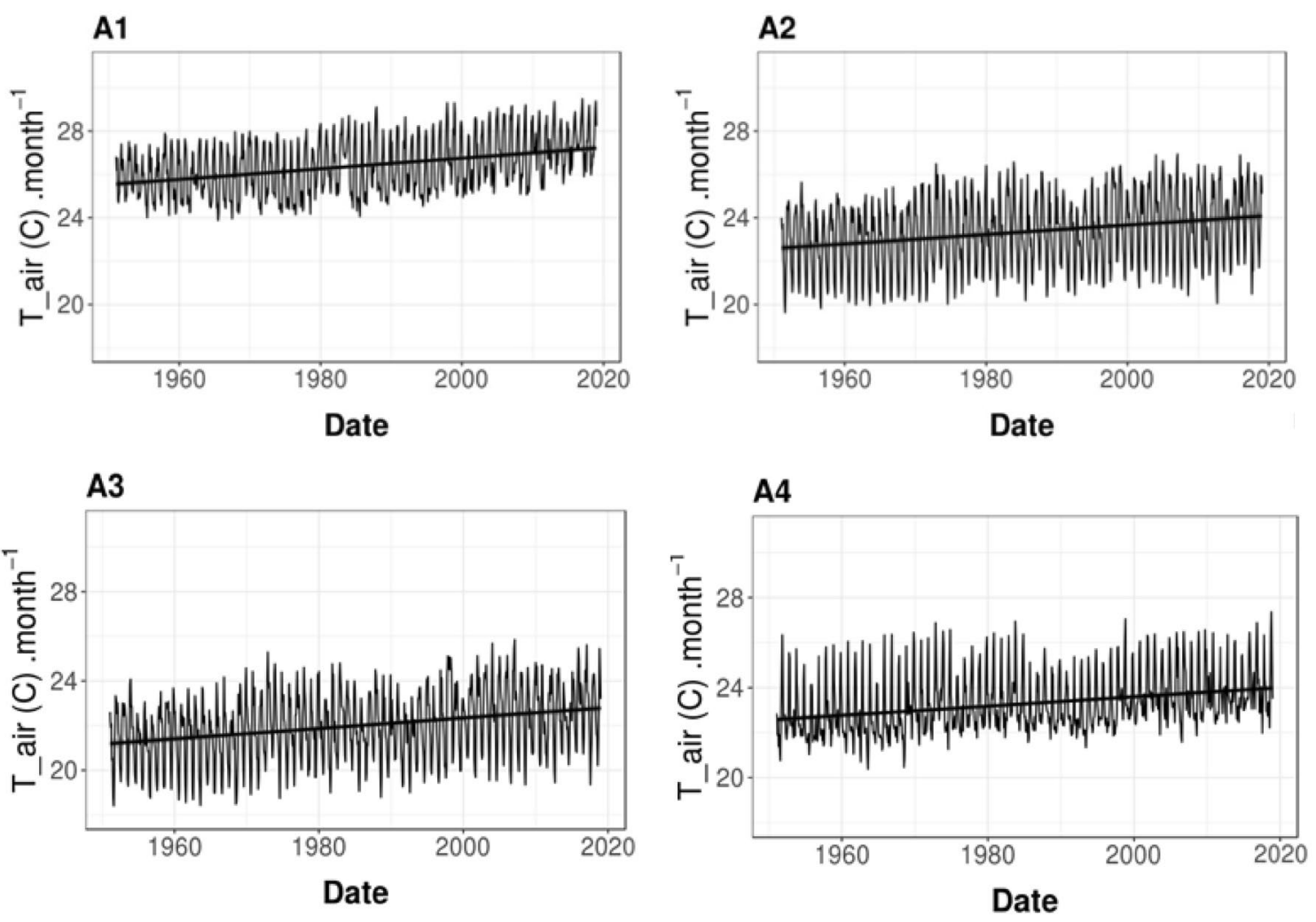

Fig. 2 Monthly mean surface T_air for the period 1951 to 2019 in the four areas studied, A1, A2, A3 and A4 
The years with the highest and lowest mean values of $T$ _air for A1 were 2016 with $29.08{ }^{\circ} \mathrm{C}$ and 1974 with $24.21{ }^{\circ} \mathrm{C}$, respectively. For $\mathrm{A} 2$, they were 1998 with $24.5^{\circ} \mathrm{C}$ and 1956 with $22.4^{\circ} \mathrm{C}$. For $\mathrm{A} 3$, the years were 2015 with $23.3^{\circ} \mathrm{C}$ and 1956 with $20.9^{\circ} \mathrm{C}$, and for $\mathrm{A} 4,2016$ with $24.4^{\circ} \mathrm{C}$ and 1955 with $22.3^{\circ} \mathrm{C}$. That is, in all the four conservation areas the highest $T$ _air values occurred in the second half of the period studied, consistent with the trends seen in Fig. 2.

Table 2 shows the decadal mean $T_{\text {_air values, for the }}$ rainy and dry seasons separately, during the period studied. First, we note that the dry season temperatures are, in general, lower than the wet season temperatures in $A 2$ and $A 3$, while the wet season temperatures are lower in $A 1$. In $\mathrm{A} 1$, the daytime convective cloudiness in the wet season masks solar radiation. In $\mathrm{A} 2$ and $\mathrm{A} 3$, the late evening rains and cloudiness do not affect the daytime temperature. A4, in general, is also warmer in the dry season.

In $\mathrm{A} 1$, the difference in the mean $T_{-}$air value between the last three decades and the first four decades was $1.11^{\circ} \mathrm{C}$ for the rainy season and $1.41^{\circ} \mathrm{C}$ for the dry season. In $\mathrm{A} 2$, the rainy season showed higher increase in temperature, $1.41^{\circ} \mathrm{C}$, compared to the dry season warming of $0.95^{\circ} \mathrm{C}$. In $\mathrm{A} 3$, the increases were almost uniform in both the seasons, $1.31^{\circ} \mathrm{C}$ for the rainy season and $1.22^{\circ} \mathrm{C}$ for the dry season. In $\mathrm{A} 4$, the increase was $1.03^{\circ} \mathrm{C}$ for the rainy season and $1.20^{\circ} \mathrm{C}$ for the dry season. Table 2 , thus, clarifies the seasonal differences in the warming trends and indicates more intense warming near the coast.

Figure 3 shows maps of the differences between the two climatologies of T_air, one for the period 1951 to 1984 and the other for 1985 to 2019. Each panel represents a month and it is possible to see the predominance of positive values in the differences over the northeast Brazil (NEB) region, indicating increases from the first 34-year mean to the last 34-year monthly mean $T_{-}$air. The annual cycle of spatial distribution of $T$ _air differences over NEB shows migration and strengthening of higher positive values from the southern portion to the center and to the northern portion, during the first half of the year. In August and September months, the differences weaken and then strengthen in November and December. There is again a weakening from December to January near the north coast which is perhaps due to the dampening of $T_{-}$air in the beginning of the rainy season in January. In austral autumn, the southward migration of the ITCZ heralds the beginning of the rainy season on the northern parts of NEB [48], which may explain why the increase in $T$-air was concentrated in the central part of the NEB during many months. The study of Santos et al. [50] already indicated an increasing trend in T_air in the states of Alagoas, Sergipe, west and northeast of Bahia from 1961 to 2007. (The political divisions of NEB are shown in Fig. 4.)

\subsection{Maxent model projections}

Figures 4, 5 and 6 show the potential intensity of presence distribution simulated by the Maxent model for the species aroeira, Carnauba and mandacaru, respectively. Potential intensity of presence can be interpreted as the probability of occurrence of a given species in a given pixel or as the percentage of the number pixels with the presence of the species in a given area. Each figure has three panels, one for the current state, second for the future state in

Table 2 Monthly mean air temperature $\left(T_{-}\right.$air $\left.{ }^{\circ} \mathrm{C}\right)$ every 10 years for $\mathrm{A} 1, \mathrm{~A} 2, \mathrm{~A} 3$ and $\mathrm{A} 4$ in the rainy and dry seasons

\begin{tabular}{|c|c|c|c|c|}
\hline Rainy season & $\mathrm{A} 1$ & $\mathrm{~A} 2$ & $\mathrm{~A} 3$ & A4 \\
\hline 1951-1959 & 25.80 & 23.55 & 22.33 & 22.57 \\
\hline 1960-1969 & 25.49 & 23.44 & 22.27 & 22.63 \\
\hline 1970-1979 & 25.46 & 23.71 & 22.98 & 23.07 \\
\hline 1980-1989 & 25.68 & 23.71 & 22.79 & 22.95 \\
\hline 1990-1999 & 25.62 & 23.82 & 22.93 & 22.90 \\
\hline 2000-2009 & 26.24 & 24.81 & 23.91 & 23.94 \\
\hline 2010-2019 & 26.92 & 24.96 & 23.65 & 23.60 \\
\hline Dry season & A1 & $\mathrm{A} 2$ & A3 & A4 \\
\hline 1951-1959 & 26.01 & 22.20 & 20.11 & 22.56 \\
\hline 1960-1969 & 26.08 & 22.20 & 20.03 & 22.31 \\
\hline 1970-1979 & 26.20 & 22.71 & 20.69 & 23.22 \\
\hline 1980-1989 & 26.78 & 22.94 & 20.80 & 23.49 \\
\hline 1990-1999 & 26.87 & 22.87 & 20.70 & 23.18 \\
\hline 2000-2009 & 27.08 & 23.02 & 21.12 & 23.45 \\
\hline 2010-2019 & 27.45 & 23.15 & 21.34 & 23.77 \\
\hline
\end{tabular}



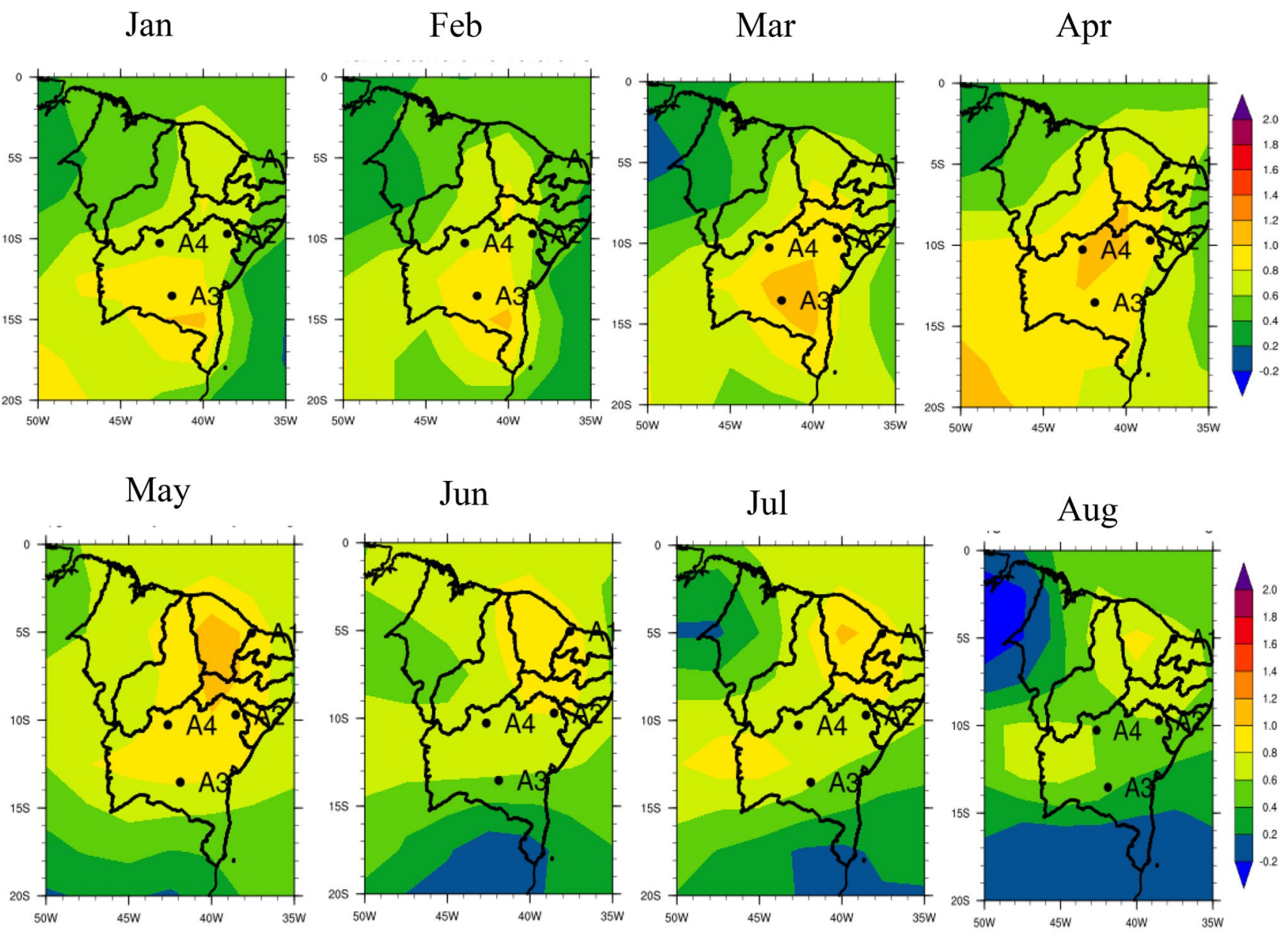

Sep

Oct

Nov

Dec
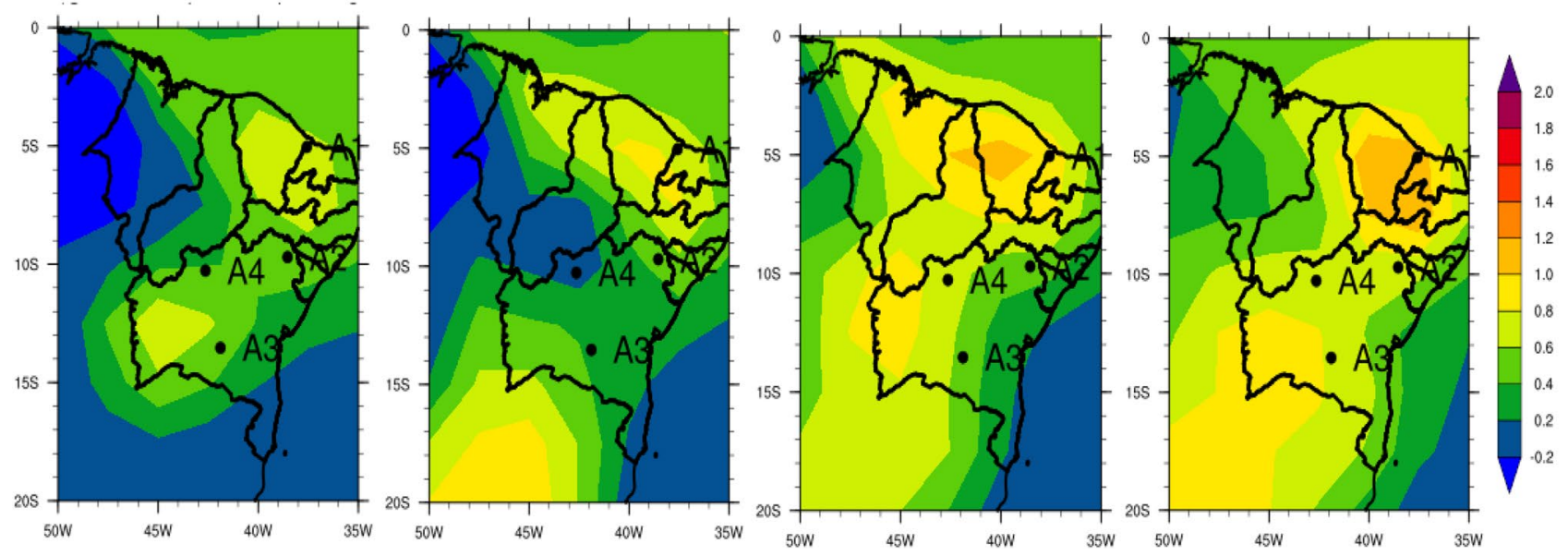

Fig. 3 Monthly climatological difference in air temperature $\left({ }^{\circ} \mathrm{C}\right)$ for the northeast Brazil region between the periods 2019-1984 and 19511984 


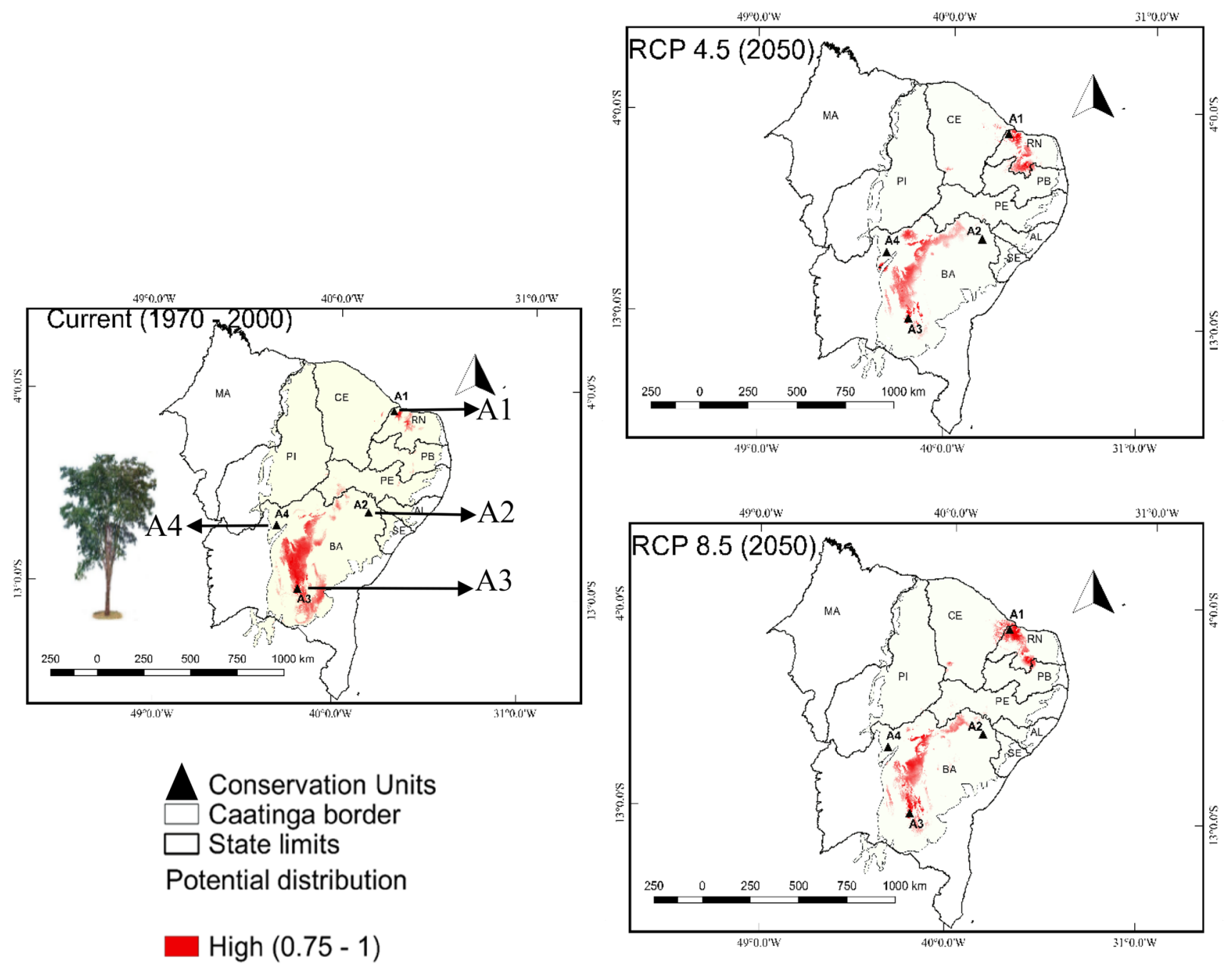

Fig. 4 Map of areas for good and high presence potential of the species Myracrodruon urundeuva Allemão (aroeira) for the current state (left panel) and for 2050, for RCP4.5 and (top right) for RCP8.5 (bottom right)

2050 with projections of the RCP4.5 scenario and the third for the future state in 2050 with projections of the RCP8.5 scenario. Areas with values above 0.75 for the potential intensities (see Table 3) are shown in red.

The gradation of potential intensities is defined as follows: pixels with values between 0 and 0.01 have null potential, between 0.01 and 0.25 have low potential, 0.25 and 0.50 have moderate potential, 0.50 and 0.75 have good potential and 0.75 to 1.0 have high potential.

Examining the areas with high potential of occurrence $(>0.75)$ for aroeira (Fig. 4), the spatial distributions in the future scenarios RCP4.5 and RCP8.5 in relation to the current state show some notable differences in the biogeographic arrangements. In the present state, high potential for the presence of the species is concentrated in Bahia state (left panel). In the future scenarios, the concentration in central Bahia is reduced and is increased in both the future scenarios (right column panels) in the state of
Rio Grande do Norte (RN). That is, a shift in the presence potential of aroeira to north is projected. Table 3 shows the expected changes in different presence potential gradations. Combining the null and low potential areas, the area is projected to increase from $31.7 \%$ in the present state to $47.0 \%$ in the future states under the RCP4.5 and RCP8.5 scenarios. The table also shows a reduction of moderate to high potential areas to about $53.0 \%$ in 2050 from $68.0 \%$ in the present state (current scenario). This shows the sensitivity of aroeira species to temperature changes. The environmental variables that most contribute to the potential occurrence of aroeira, obtained from PCA, are the mean annual temperature (Bio1), isothermality (Bio3) and precipitation in the coldest quarter (Bio19). Surprisingly, the difference between the two RCPs is small, although the increase in air temperature in the Caatinga phytogeographic domain in the RCP8.5 scenario is $3^{\circ} \mathrm{C}$ compared to $2^{\circ} \mathrm{C}$ for the RCP 4.5 scenario. 


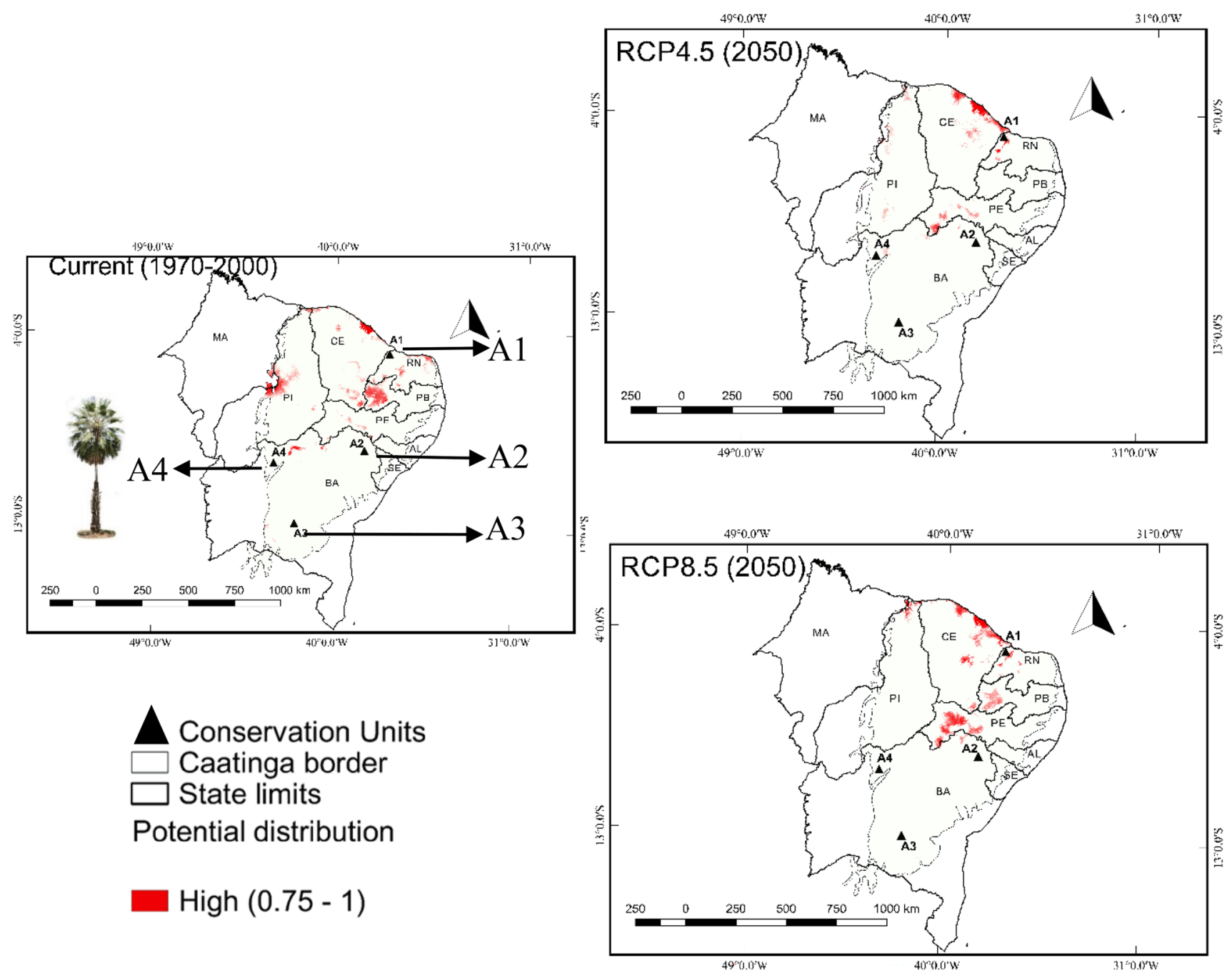

Fig. 5 Map of high potential areas for the presence of the species Copernicia prunifera (carnaúba) for the current state (left), RCP4.5 and RCP8.5 scenarios (right column)

The areas with the greatest potential for the occurrence of Carnauba in the present state are situated mostly in the state of Ceará (CE), Paraíba (PB) and Piaui and are spotty (Fig. 5). They are places with good drainage. In the future scenarios (panels in the right column, Fig. 5), the high potential areas shrink or disappear in Piaui and Paraiba and appear in the coastal places of Ceará and in the extreme western portion of Pernambuco state. Table 4 shows the expected changes in the presence potential of the species in future scenarios compared to the present state in different gradations of potential. The combined good and high potential areas decrease slightly from $25.3 \%$ in the present state to $24.0 \%$ in the RCP4.5 scenario and to $19.5 \%$ in the RCP 8.5 scenario. A shift in the habitat suitable for the occurrence of Carnauba from the interior of the region to the coast of Ceará is notable.
The results of the PCA showed that the variables that most contribute to the presence of Carnauba are: minimum temperature in the coldest month $\left({ }^{\circ} \mathrm{C}\right)(\mathrm{Bio6})$, precipitation in the driest quarter $(\mathrm{mm})$ (Bio17) and precipitation in the warmest quarter ( $\mathrm{mm}$ ) (Bio18). This information suggests that the species adapts well to places with temporal water stress. Field data indicate that the carnauba species adapts well to intermittent wetlands, withstanding periods of flood and drought [12].

Mandacarú habitat with good and high potential is present in $\mathrm{PB}, \mathrm{RN}$ and the eastern parts of $\mathrm{BA}$ in the present state (Fig. 6). Cavalcante et al. [5] mentioned that it is a species of low demand of water that can occur over a large part of the phytogeographic domain. However, in the present study, the high potential for its presence is seen more concentrated over the eastern belt of the Caatinga phytogeographic domain. The projections 


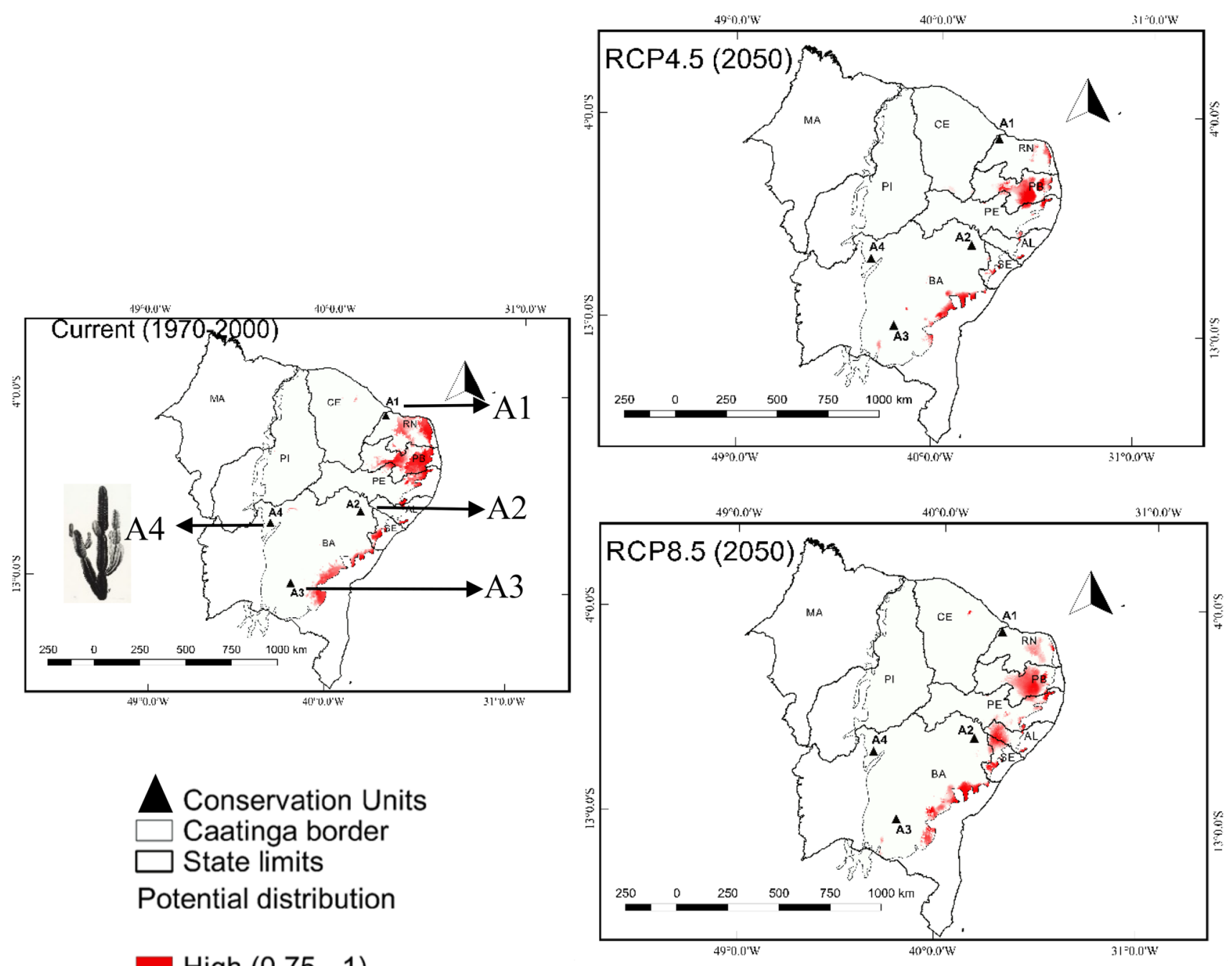

Fig. 6 Map of potential areas for the presence of the species Cereus jamacaru DC (mandacaru) for the current state (left), RCP4.5 (top right) and RCP8.5 (bottom right)

Table 3 Percentage of pixels (\%) in the Caatinga phytogeographic domain map with values in different gradation intervals for aroeira

\begin{tabular}{llcc}
\hline Potential distribution & Current scenario & RCP4.5 & RCP8.5 \\
\hline Nul & 4.64 & 18.59 & 18.08 \\
Low & 27.08 & 28.81 & 28.77 \\
Moderate & 37.55 & 24.05 & 23.92 \\
Good & 20.87 & 20.10 & 20.65 \\
High & 10.00 & 8.50 & 8.60 \\
\hline
\end{tabular}

for future scenarios indicate that the areas with good potential will reduce in $\mathrm{RN}$ and will increase in western parts of the states of Alagoas and Sergipe. In the current scenario, there is $23.5 \%$ of the area with a good or high potential for the presence of the species. In the RCP4.5 scenario, this value decreases to $17.5 \%$, and in RCP8.5, it
Table 4 Same as Table 3 but for carnauba species

\begin{tabular}{lcrc}
\hline Potential distribution & Current scenario & RCP4.5 & RCP8.5 \\
\hline Null & 9.17 & 7.35 & 13.57 \\
Low & 39.07 & 39.09 & 36.49 \\
Moderate & 26.41 & 29.47 & 30.50 \\
Good & 19.06 & 20.28 & 14.29 \\
High & 6.24 & 3.73 & 5.20 \\
\hline
\end{tabular}

jumps to $22.9 \%$ (Table 5). In the extreme RCP8.5 scenario, the rainfall changes may be favoring a rise in the distribution potential of mandacarú compared to RCP4.5. Areas with null and low potential for mandacarú species for the current scenario are $39.7 \%$, increasing to $62.5 \%$ in the RCP4.5 scenario and decreasing to $44.0 \%$ in the RCP8.5 scenario (Table 5). 
Table 5 Same as Table 3 but for mandacaru species

\begin{tabular}{lcrr}
\hline Potential distribution & Current scenario & RCP4.5 & RCP8.5 \\
\hline Null & 0.7 & 9.86 & 0.10 \\
Low & 39.01 & 52.86 & 43.91 \\
Moderate & 37.39 & 19.78 & 33.17 \\
Good & 14.14 & 12.15 & 14.37 \\
High & 9.38 & 5.38 & 8.50 \\
\hline
\end{tabular}

The variables that most contribute to the species distribution is precipitation in the driest month $(\mathrm{mm})$ (Bio14), followed by precipitation in the wettest month $(\mathrm{mm})($ Bio13) and precipitation in the warmest quarter $(\mathrm{mm})$ (Bio18). That is, it does not depend on temperature changes in the future scenarios as much as it depends on the precipitation. Mandacaru blooms in the rainy season [63] and presents seasonal reproductive events linked to the rainy season. The fruiting strategy during the beginning of the rainy season allows for greater efficiency in the germination process with greater use of water in the soil [32], 42].

Lastly, the average AUC values found in the present study for the three species were 0.84 for aroeira, 0.87 for carnaúba and 0.83 for mandacaru. AUC value over 0.8 indicates good accuracy of the model, and therefore, the potentials of presence presented above can serve as a guide for future estimates of evolution of the three species.

\section{Discussion}

We observe that $\mathrm{A} 1$ has higher $T_{-}$air values than the other three areas, despite being the place with the highest rainfall among the four conservation areas studied due to its location in a low lying area with an average altitude of about $100 \mathrm{~m}$. The lowest monthly mean values of $T$ _air observed in $A 3$, although it receives only $753 \mathrm{~mm}_{\text {year }}{ }^{-1}$ of rain, are due to its location in a well-drained region, with several bodies of water around the conservation area and with high levels of Improved Vegetation Index [59], in press), which may contribute to cooling the air temperature.

In general, the years with the lowest mean air temperature record for all locations were concentrated in the first climatology (1951-1984) and the highest mean air temperature values were recorded in the second climatology (1984-2019), which indicates warming. In the respective years in which there was maximum and minimum $T_{\text {_air }}$ for the analyzed regions, El Niño (possible cause of higher temperatures than normal) and La Niña (possible cause of lower temperatures) events also contributed. The A2 area, however, registered higher $T_{\text {_air }}$ in the La Nina year 2008 and lower T_air in El Niño year 1963, the reasons for which need investigation. Studies focusing on the El Niño and La Niña episodes have shown that these events can influence the rainfall pattern over NEB and, consequently, interfere with the air temperature $[28,29]$. El Niño aggravates the lack of rain in the NEB region, influencing the increase in air temperature. The changes observed in $T_{-}$air were also reported in other works, such as Marengo [33] who presented projections for the twenty-first century pointing to warming throughout Brazil, reduction in precipitation in NEB, possibly as a cause of global warming and an increase in $T$ _air at the end of the twenty-first century [35].

The increase in $T$ aair, when associated with vegetation suppression, leads to aridification. Even in the so-called conservation units with a large extension of Caatinga vegetation, there was an increase in $T_{-}$air. This can increase the risk of hydrological deficiency in the region by favoring an increase in the rate of evaporation. In addition, a greater number of hours of exposure to sun (approximately $3.000 \mathrm{~h}$ of sun per year) can further aggravate the hydrological deficit in this region for most of the year [2].

Salazar et al. [49] estimated a aridification situation in the semiarid northeast in the period 2090-2099, for an air temperature increase scenario of $2-6^{\circ} \mathrm{C}$ in the $\mathrm{A} 2$ region, and $1-4{ }^{\circ} \mathrm{C}$ in the $\mathrm{A} 1$ region, indicating a direct influence on the characteristics and distribution of vegetation. Thus, changes in $T_{-}$air values will have a direct influence on vegetation characteristics and distribution.

Kumar et al. [30] explained that part of the upward trend in $T_{\text {_air }}$ is not only due to global warming but also due to the higher frequency of El Niño events. It is important to emphasize that factors such as the increase in urban areas, reduction of vegetation cover, change in the atmospheric composition due to the increase in gases such as carbon dioxide $\left(\mathrm{CO}_{2}\right)$, all contribute to the change in $T_{\text {_air }}[50]$. In the state of Paraíba, for example, Dantas et al. [10] showed an increase in air temperature, and they attributed this to the density of buildings, change in land use and urban growth.

The Maxent model utilized to project future situation of plant species directly depends on the existing species occurrence data, and thus, the output is sensitive to the quality of observed data. Errors in the latitude and longitude position in the occurrence data may cause the model make imprecise projections. For example, a species known to be endemic to the Amazon Basin may make its presence in the geographic area of Caatinga. Sometimes, in the place of the coordinates of the location of a species the coordinates of the nearby city are coded. It is also found that the resolutions of the numerical values at different places are different and these data are thoroughly scrutinized before feeding to the model. 
Precipitation, photoperiod and air temperature are related to flowering, fruiting, fall and sprouting of the mastic tree [44]. While precipitation positively affects the production of new leaves and budding, it is in the reduction of rainfall that flowering, fruiting and leaf fall occur, and it is only with increase in air temperature that the fruit ripens, showing a direct influence of rainfall and air temperature in the reproductive and vegetative phenophase [41].

In the annual average temperature map (Bio1, not shown) for the current climate, the occurrence of aroeira is concentrated in areas with air temperature between 20 and $30^{\circ} \mathrm{C}$, which is the same air temperature range considered optimal for germination of its seeds according to Medeiros et al. [34]. In the scenario RCP4.5, it is observed that there is an expansion of areas to the north of the phytogeographic domain and coastal areas with increased air temperature. The details of the relationship between this species and environmental variables are not very clear. It can be said, however, that this species needs a dry period, with an increase in $T_{-}$air, for the maturation of its fruits. $T$ air is the only factor that affects the occurrence of ripe fruits [41].

A survey carried out to determine the relationship between climatic factors and aroeira seed germination and the trend of this germination for future climate scenarios showed that a reduction of the number of weeks with minimum rainfall directly affects seed germination and seedling recruitment, and that the quality of the seeds produced by aroeira is directly related to the maximum, average and minimum temperatures, average and minimum humidity, indicating that fluctuations in climate variables will lead to a reduction in the physiological quality of the seeds [43].

A study carried out by Francisco et al. on the detection of changes in the Caatinga vegetation showed that places with greater potential for recovery have alluvial soils with greater moisture available during the year and Litholic Neossolos in areas of steeper slope. In the state of Paraíba, for example, the central region showed low potential for the presence of Carnauba in the current scenario, worsening in scenarios RCP4.5 and RCP8.5. The central region, where the Taperoá river basin is located, is currently in the process of aridification as per Francisco et al. The potential for occurrence is lower in all places which are already susceptible to aridification.

Mandacaru is one of the main species, of the Cactaceae family, found in Brazil [6], it is a highly resistant species that adapts to places with little water resource. Despite its adaptation to the semiarid climate, mandacaru may suffer the effect of global climate changes that may favor the advance of aridification, and influence the distribution of this species [26]. In general, there is a spatial variation in the distribution of mandacaru in the two RCP scenarios, with a decline in the species abundance compared to the current scenario. The increased distribution of the species in the RCP8.5 scenario compared to RCP4.5 can be explained by its resistance to the dry period.

The increase in air temperature and the reduction of rainfall in the RCP scenarios can contribute to the aridification process, with negative consequences especially in the RCP8.5 scenario where there is spatial expansion of the mandacaru over a large part of the Caatinga with AUC values considered good, featuring an arid landscape. Williams et al. [61] explain the adaptation of cacti as a relationship between the physical structure of the species (morphology) and the climate conditions where the species will be established.

In an attempt to contain the advance of the degradation of native vegetation and aridification, the conservation areas created by the Federal Government in the Caatinga are of great importance. With the creation of such units, the protected area for conservation increased in the phytogeographic domain by about $7.5 \%$ of the total area of Caatinga. Even so, this will continue as one of the least protected phytogeographic domain in the country, as just over $1 \%$ of these units are fully protected [39].

\section{Conclusion}

Taking into account current and future climate conditions and biotic data for species distribution models, we observe that there is a possibility of contraction of area with high distribution potential for the three target species and expansion of areas with low potential by the end of this century.

The time series of $T_{-}$air for the four areas of the Caatinga phytogeographic domain in northeast Brazil (NEB) studied here showed positive trends, indicating that important changes are present in the data. For all the four areas, the periods of increase in $T_{\text {_air }}$ were accompanied by a reduction in rainfall, which could lead to an increase in the aridification process. The records of El Nino and La Nina, in the same years as warmer and less warm years, may indicate the influence of the phenomenon on local climate conditions. The conservation areas studied here represent less than $12 \%$ of the region, and a large part of it has already been deforested, aggravating the increase in $T$ air. The deforestation, in addition to the global warming, can worsen the temperature rise.

The Maxent model results for the three important vegetation species in the phytogeographic domain indicate future reductions in potential areas for their presence. In the most catastrophic scenario, RCP8.5, the reduction in species presence is more accentuated for Carnauba, followed by aroeira and mandacaru. In the conservation 
areas A1 and A4 (Fig. 1), high distribution potentials are observed for the aroeira and carnaúba species in the current scenario and in RCP4.5. These areas are the ones that register the highest values of annual precipitation.

In A3, despite being an area with little more than $700 \mathrm{~mm}$ year ${ }^{-1}$ of rain, there is a high potential for the distribution of aroeira and mandacaru, possibly as a consequence of the local hydrology. This may be the explanation for the high distribution potential that is maintained in this conservation unit in the future scenarios also.

A2 is an area with rarefied soils and dominated by shrub and herbaceous vegetation. In addition to these conditions found in the field, it is an area with very little annual rainfall. This may be the reason for the species occurrence potential to fluctuate between low and moderate for all the three species.

The possibility of the absence of these species in near future (approximately 30 years) may have consequences for the maintenance of animals and affect the local economy, since these species are highly productive and present high economic value. Its absence can pose a serious social and environmental problem. Thus, further investigations to monitor the increase in $T$ _air and the consequences of this change for the vegetation of the Caatinga phytogeographic domain are needed.

Acknowledgements We would like to thank National Institute for Space Research (INPE). Third author is grateful for the CNPq Productivity Grant No. 301370/2017-6, and CAPES PVNS Grant No. 23038.019802/2018-07.

Funding This study was funded by the National Council for Scientific and Technological Development.

\section{Declarations}

Conflict of interest The authors declare that they have no conflict of interest.

Open Access This article is licensed under a Creative Commons Attribution 4.0 International License, which permits use, sharing, adaptation, distribution and reproduction in any medium or format, as long as you give appropriate credit to the original author(s) and the source, provide a link to the Creative Commons licence, and indicate if changes were made. The images or other third party material in this article are included in the article's Creative Commons licence, unless indicated otherwise in a credit line to the material. If material is not included in the article's Creative Commons licence and your intended use is not permitted by statutory regulation or exceeds the permitted use, you will need to obtain permission directly from the copyright holder. To view a copy of this licence, visit http://creativecommons. org/licenses/by/4.0/.

\section{References}

1. Asfaw A, Simane B, Hassen A, Bantider A (2018) Variability and tome series trend analysis of rainfall and temperature in northcentral Ethiopia: a case study in Woleka sub-basin. Weather Clim Extrem 19(1):29-41

2. Bezerra NF (2002). Água e desenvolvimento sustentável no semiárido. FUNCEME. Fortaleza: fundação konrad adenauer, série debates $n^{\circ} 24$, dezembro

3. Blain GC (2011) Considerações estatísticas relativas a seis séries mensais de temperatura do ar da secretaria de agricultura e abastecimento do Estado de São Paulo. Rev Bras Meteorol 26(2):279-296. https://doi.org/10.1590/S0102-7786201100 0200012

4. Cavalcante MB (2009) Ecoturismo no bioma caatinga: o caso do parque estadual da pedra da Boca, Paraíba. Rev Nordestina Ecotur Aracaju 2(1):25-38

5. Cavalcante AMB, Sampaio ACP (2019) Modelando a distribuição geográfica corrente do cereus jamacaru no bioma caatinga. In: Simpósio brasileiro de geografia física aplicada,18, Fortaleza, CE. Anais. 2019. DVD. Available at: http:// sbgfa.com.br. Accessed on 30 June 2019

6. Cavalcanti NB, Resende GM (2007) Consumo de xiquexique (Pilocereus gounellei (A. Weber ex K. Schum.) Bly. ex Rowl) por caprinos no semi-árido da Bahia. Revista Caatinga, Mossoró 20(1):22-27

7. CNCFLORA (2012). Myracrodruon urundeuva in lista vermelha da flora brasileira versão 2012.2 centro nacional de conservação da Flora. Disponível em http://cncflora.jbrj.gov. $\mathrm{br} /$ portal/pt-br/profile/Myracrodruon urundeuva. Accessed on 19 Nov 2020

8. Cubasch U, Wuebbles D, Chen D, Facchini MC, Frame D, Mhowald N, Winther JG (2013) The physical science basis. Contribution of working group I to the fifth assessment report of the intergovernmental panel on climate change. Cambridge University Press, Cambridge, pp 119-158

9. CPRM, Serviço geológico do Brasil (2016) Available in: http:// www.cprm.gov.br/publique///Mapas-e-Publicacoes/AtlasPluviometrico-do-Brasil-1351.html

10. Dantas LG, Santos CAC, Olinda RA (2015) Tendências anuais e sazonais nos extremos de temperatura do ar e precipitação em Campina Grande - PB. Rev Bras Meteorol 30:297-308

11. Dalapicolla J (2016) Tutorial de modelos de distribuição - guia teórico

12. D'alva OA (2004) O extrativismo da carnaúba no Ceará 2004. 192 f. Dissertação (mestrado) - Universidade Federal do Ceará, Núcleo de Pós-Graduação, Programa Regional de Pós-Graduação em Desenvolvimento e Meio Ambiente, Fortaleza, Brazil

13. Duque JG (2004) Solo e água no polígono das secas, 6 th edn. Banco do Nordeste do Brasil, Fortaleza

14. Elith J, Graham CH, Anderson RP (2006) Novel methods improve prediction of species' distributions from occurrence data. Ecography 29:129-151

15. Elith J, Kearney M, Phillips SJ (2010) The art of modelling range-shifting species. Methods Ecol Evol 1:330-342

16. Ferretti AR, Kageyama PY, Árbocz GF, Santos JD, Barros MI, Lorza RF, Oliveira C (1995) Classificação das espécies arbóreas em grupos ecológicos para revegetação com nativas no estado de São Paulo. Florestar Estat 3:73-77

17. Francisco PR (2013) Os Limites do Semiárido Brasileiro. pp 163-181

18. GBIF (2021) Global biodiversity information facility. Occurrence download. Disponível em: https://www.gbif.org/. Accessed in Jan 2021 
19. Gomes P (1972) Forragens fartas na seca. Nobel, São Paulo. $p$ 360

20. Guimarães SO, Costa AA, Vasconcelos Júnior FC, Silva EM, Sales DC, Araújo Júnior LM, Souza SG (2016) Projeções de Mudanças Climáticas sobre o Nordeste Brasileiro dos Modelos do CMIP5 e do CORDEX. Revista Brasileira de Meteorologia, São Paulo 31(3):337-365. https://doi.org/10.1590/0102-7786313201 50150

21. Hijmans RJ, Cameron SE, Parra JL, Jones PG, Jarvis A (2005) Very high resolution interpolated climate surfaces for global land areas. Int J Climatol 25:1965-1978

22. IBGE - INSTITUTO BRASILEIRO DE GEOGRAFIA E ESTATÍSTICAIBGE (2007) Mapa de biomas do Brasil, primeira aproximação. Disponível em: www.ibge.gov.br. Acesso em: 02 de março de 2021

23. Instituto Brasileiro de Geografia E Estatística-IBGE (2021) Mapa de biomas do Brasil, primeira aproximação. Rio de Janeiro, 2004. Disponível em: www.ibge.gov.br Acesso em 02 de março de 2021

24. Instituto Brasileiro de Geografia E Estatística - IBGE (2021) Cidades@2005. Accessed on 27 Jan 2021

25. Instituto Chico Mendes de Conservação da Biodiversidade (ICMBIO) (2020) Conservação. Available at: https://www.icmbio.gov. $\mathrm{br} / \mathrm{cma} / \mathrm{mapa}$-do-site.html. Accessed in Mar 2021

26. IPCC (2013) Climate change - the physical science basis. In: Stocker TF, Qin D, Plattner GK, Tignor M, Allen SK, Boschung J, Nauels A, Xia Y, Bex V, Midgley PM (eds) Working group I contribution to the fifth assessment report of the intergovernmental panel on climate change. Cambridge University Press, Cambridge, New York, p 1535

27. Kalnay E et al (1996) The NCEP/NCAR 40-year reanalysis project. Bull Am Meteorol Soc 77:437-471

28. Kayano MT, Andreoli RV (2004) Decadal variability of northern northeast Brazil rainfall and its relation to tropical sea surface temperature and global sea level pressure anomalies. J Geophys Res. https://doi.org/10.1029/2004JC002429

29. Kayano MT, Andreoli RV (2006) Relationships between rainfall anomalies over northeastern Brazil and the El Nin o Southern Oscillation. J Geophys Res 111:D13101

30. Kumar KK, Kleeman R, Crane MA, Rajagopalan B (1999) Epochal changes in Indian monsoon-ENSO precursors. Geophys Res Lett 26:75-78

31. Kendall MG (1975) Rank correlation measures. Charles Griffin, London, p 220

32. Lucena EARM (2007) Fenologia, biologia da polinização e da reprodução de Pilosocereus Byles \& Rowley (Cactaceae) no Nordeste do Brasil. 185 f. Tese de Doutorado (Programa de PósGraduação em Biologia Vegetal). Universidade Federal de Pernambuco. Recife, Brazil

33. Marengo JA (2006) Mudanças climáticas globais e seus efeitos sobre a biodiversidade: caracterização do clima atual e definição das alterações climáticas para o território brasileiro ao longo do século. Ministério do Meio Ambiente, Brasília, DF. p 159 (Biodiversidade, 26)

34. Mann HB (1945) The econometric society. Econometrica 13(3):245-259

35. Marengo JA, Ambrizzi T, Rocha P, Alves LM, Cuadra SV, Valverde MC, Ferraz SET, Torres RR, Santos DC (2009) Future change of climate in South America in the late XXI century: intercomparison of scenarios from three regional climate models. Clim Dyn. https://doi.org/10.1007/s00382-009-0721-6

36. Marengo JA, Alves LM, Beserra E, Lacerda F (2011) Variabilidade e mudanças climáticas no semiárido brasileiro. In: Medeiros SS, Gheyi HR, Galvão CO, Paz VPS (Orgs.). Recursos Hídricos e, Regiões Áridas e Semiáridas. INSA, Campina Grande-PB, pp 383-416
37. Medeiros SS, Cecilio RA, Melo Junior JCF, Silva Junior JLC (2005) Estimativa e especialização das temperaturas do ar mínimas, médias e máximas na região nordeste do Brasil. Rev Bras de Engenharia Agrícola e Ambiental, Campina Grande, Paraíba 9(2):247-255

38. Ministério do Meio Ambiente (MMA) (2006) Projeto de conservação e utilização sustentável da diversidade biológica brasileira: relatório de atividades. Ministério do Meio Ambiente, Brasília

39. Ministério do Meio Ambiente (MMA) (2014) Biodiversidade e conservação. Disponível em: http://www.mma.gov.br/biodiversi dade/conservacaoe-promocao-do-uso-dadiversidade-genet ica/agrobiodiversidade/variedades-crioulas-e-parentessilvest res/itemlist/category/55-Caatinga.html. Accessed in Mar 2021

40. Neeti N, Eastman R (2011) A contextual Mann-Kendall approach for the assessment of trend significance in image time series. T GIS 15:599-611. https://doi.org/10.1111/j.1467-9671.2011. 01280.X

41. Nunes YRF et al (2008) Aspectos ecológicos da aroeira (Myracrodruonurundeuva Allemão- Anacardiaceae): fenologia e germinação de sementes. Rev Árvore Viçosa 32(2):233-243. https:// doi.org/10.1590/S0100-67622008000200006

42. Oliveira ISS (2017) Ecologia da reprodução de pilosocereus catingicola (Gürke) Byles \& Rowley subsp. Salvadorensis (Werderm.) Zappi (Cactaceae): FENOLOGIA e biologia floral em população natural no brejo

43. Oliveira GM (2019) Vulnerabilidade de sementes de aroeirado-sertão (Myracrodruon urundeuva Allemão) às mudanças climáticas globais. UEFS - Universidade Estadual de Feira de Santana, Tese, p 97

44. Pedroni F, Sanchez M, Santos FAM (2002) Fenologia da copaíba (Copaifera langsdorffii Desf. - Leguminosae, Caesalpinioideae) em uma floresta semidecídua no sudeste do Brasil. Rev Bras Bot 25(2):183-194

45. Pettitt AN (1979) A non-parametric approach to the changepoint problem. Appl Stat 28(2):126-135

46. Pereira Junior LR et al (2014) Espécies da Caatinga como alternativa para o desenvolvimento de novos fitofármacos. Floresta Ambient Seropédica 21(4):509-520

47. Phillips SJ et al (2006) Maximum entropy modeling of species geographic distributions. Ecol Model 190:231-259

48. Reboita et al (2012) Entendendo o tempo e o clima na américa do sul. Funceme, Fortaleza, CE, Brazil

49. Salazar LF, Nobre CA, Oyama MD (2007) Climate change consequences on the phytogeographic domain distribution in tropical South America. Geophys Res Lett 34:2-7. https://doi.org/10. 1029/2007GL029695

50. Santos DN, Silva VPR, Sousa FAS, Silva RA (2010) Estudo de alguns cenários climáticos para o Nordeste do Brasil. Rev Bras Eng Agríc Ambient 14(5):492-500

51. Santos NA (2016) Modulação regional da precipitação e temperatura da superfície do mar no Estado da Bahia. 88 f. Dissertação (Mestrado em Meteorologia) - Programa de Pós-Graduação em Meteorologia, Centro de Tecnologia e Recursos Naturais, Universidade Federal de Campina Grande, Campina Grande, Paraíba, Brasil

52. Seddon AWR et al (2016) Sensitivity of global terrestrial ecosystems to climate variability. Nature 531(7593):229-232. https:// doi.org/10.1038/nature16986

53. Schmidt DM, Lima KC, Jesus ES (2018) Variability climatic of water availability in the semiarid of the state of rio grande do norte. Anu do Inst Geo (UFRJ. IMPRESSO) 41:483-491

54. Silveira CS et al (2016) Mudanças climáticas na bacia do rio São Francisco: uma análise para precipitação e temperatura. RBRH Porto Alegre 21(2):416-428 
55. Sousa RM et al (2019) Projeções climáticas regionalizadas para o estado do tocantins, Brasil, nos Cenários RCP 4.5 E RCP 8.5. Rev Bras Climatol 24:2237-8642

56. Thom HCS (1966) Some methods of climatological analysis. Secretariat of the World Meteorological Organization, Geneva

57. Van Vuuren DP, KainumA M, Riahi K, Thomson A, Hibbard K, Hurtt GC, Ram T, Krey V, Lamarque J, Masui T, Meinshausen M, Nakicenovic N, Smith S, Rose SK (2011) The representative concentration pathways: an overview. Clim Change 109(1-2):5-31

58. Velloso AL, Everardo VSB, Sampaio EVSB, Pareyn FGC (ed) (2002) Seminário de planejamento ecorregional da caatinga $1^{\text {a }}$ ETAPA TNC/PNE - the nature conservancy do Brasil/associação plantas do nordeste. Ecorregiões propostas para o bioma caatinga: resultados do seminário de planejamento ecorregional da Caatinga 1a etapa. In: Electronic version, 1, Editora Flamar, Recife- PE, Brazil

59. Vieira LCS, Filho VPS, Dantas VA (2020) Sazonalidade do sequestro de carbono em áreas de Caatinga e quantificação do seu estoque nas estações seca e chuvosa. Rev Bras Meteorol

60. Warren DL, Wright AN, Seifert SN, Shaffer HB (2014) Incorporating model complexity and spatial sampling bias into ecological niche models of climate change risks faced by 90 California vertebrate species of concern. Divers Distrib 20:334-343
61. Williams DG, Hultine KR, Dettman DL (2014) Functional tradeoffs in succulent stems predict responses to climate change in columnar cacti. J Exp Bot 65(13):3405-3413. https://doi.org/10. 1093/jxb/eru174

62. Yue S, Pilon P, Cavadias G (2002) Power of the mann-kendall and spearman's rho tests for detecting monotonic trends in hydrological series. J Hydrol 259:254-271. https://doi.org/10.1016/ S0022-1694(01)00594-7

63. Zanina DN (2013) Quem poliniza cereus jamacarú? $40 \mathrm{f}$. Dissertação (Mestrado) - curso de pós-graduação em ecologia e recursos naturais. Universidade Federal do Ceará, Fortaleza, Brazil

64. Zhang W, Yan Y, Zheng J, Li L, Dong X, Cai H (2009) Temporal and spatial variability of annual extreme water level in the Pearl River Delta region. China Glob Planet Change 69:35-47

Publisher's Note Springer Nature remains neutral with regard to jurisdictional claims in published maps and institutional affiliations. 